\title{
Effects of entomopathogenic nematodes Steinernema carpocapsae and Heterorhabditis bacteriophora on the fitness of a Vip3A resistant subpopulation of Heliothis virescens (Noctuidae: Lepidoptera)
}

\author{
Asim Gulzar 1,2,* (D), Tariq Mukhtar ${ }^{3}$ (D), Denis John Wright ${ }^{1}$ (D) \\ 1. Imperial College London - Silwood Park Campus - Department of Life Sciences - Ascot, UK. \\ 2. Pir Mehr Ali Shah Arid Agriculture University - Department of Entomology - Rawalpindi, Pakistan. \\ 3. Pir Mehr Ali Shah Arid Agriculture University - Department of Plant Pathology - Rawalpindi, Pakistan.
}

\begin{abstract}
The widespread use of transgenic plants imposes selection pressure on insect pest populations to develop insecticide resistance. Evaluation of effectiveness of resistance management strategies is very important in resistance management programs. Resistance management to insecticides is widely believed to depend in part on associated fitness costs. Fitness costs can delay the development of resistance. In the present study, the effects of two entomopathogenic nematode species, Steinernema carpocapsae and Heterorhabditis bacteriophora were studied on the fitness of first insect population of Heliothis virescens selected with Vip3A in the laboratory. It was found that both nematodes species increased the fitness cost of Vip3A selected insects. The mortality of the Unsel subpopulation after exposure to either nematode species was significantly lower than that of the Vip3A-Sel subpopulation. Likewise, the reproduction of both nematode species was significantly greater in cadavers of the Unsel compared with the Vip3A-Sel subpopulation of $H$. virescens. There was positive correlation between nematode reproduction and the larval instar infected with nematodes. The penetration of infective nematode juveniles (IJ) was greater in the Vip3A-Sel subpopulation than in the Unsel subpopulation of $H$. virescens. It is concluded that entomopathogenic nematodes could increase the fitness costs and subsequently delay the resistance.
\end{abstract}

Key words: fitness costs, entomopathogenic nematodes, Heliothis virescens, mortality.

\author{
Received: \\ Dec. 23, 2019 \\ Accepted: \\ Feb. 3, 2020 \\ Section Editor: \\ Gabriel Constantino Blain \\ ${ }^{\star}$ Corresponding author: \\ asim@uaar.edu.pk
}

\section{INTRODUCTION}

Genetically modified plants expressing insecticidal crystal (Cry) proteins derived from Bacillus thuringiensis (Bt) have been one of the major successes of applying genetic engineering technologies to agriculture (Gatehouse 2008; Gulzar et al. 2012; Gulzar and Wright 2014). These crops are effective against many lepidopteran pest species and with the introduction of Bollgard I (expressing Cry1 Ac), Bollgard II (Cry1 Ac and Cry 2Ab) (Monsanto, St Louis, USA) and WideStrike (Cry1 Ac and Cry1F) (Dow Agro Sciences, Indianapolis, USA) cotton, key pests such as Heliothis virescens and Pectinophora gossypiella have been effectively controlled (Greenplate et al. 1999; Jackson et al. 2007; Llewellyn et al. 2007). Although these Bt crops and commercially available Bt spray formulations provided an important alternative to chemical insecticides to control the pests, their widespread use could increase the risk of the development of Bt resistance in insects (Ferré and Van Rie 2002; Gassmann et al. 2009). Lepidopteran species, Plutella xylostella, Helicoverpa zea, Spodoptera frugiperda and Bussiola fusca 
have developed resistance to Bt Cry toxins in the field, while Trichoplusia ni has developed resistance to Cry1 Ac in some greenhouse populations (Janmaat and Myers 2005).

Genetically modified crops expressing toxins, which are likely to have no cross-resistance with Cry toxins are therefore of interest. One such group of toxins are the vegetative insecticidal proteins (Vip) produced during vegetative growth of $\mathrm{Bt}$ (Estruch et al. 1996; Selvapandiyan et al. 2001), which show broad-spectrum insecticidal activity against many lepidopteran (Vip3A) (Lee et al. 2003; Hernández-Martínez et al. 2013; Chakroun et al. 2016) and coleopteran pest species (Vip1 and Vip2) (Warren 1997). Vip toxins have a different mode of action (Lee et al. 2003) and no sequence homology compared with Cry toxins (Estruch et al. 1996; Lee et al. 2003; Chakroun et al. 2016).

Heliothis virescens is an important, highly polyphagous pest (Neunzig 1969; Sudbrink and Grant 1995; Gulzar and Wright 2015). Its distribution extends through North and South America, with a permanent population between $40^{\circ} \mathrm{N}$ and $40^{\circ} \mathrm{S}$ (Neunzig 1969; Fitt 1989; King 1994; McCaffery 1998). It attacks a wide range of important food, fiber, oil crops and is one of the key pests of cotton in America (Fitt 1989; Terán-Vargas et al. 2005; Blanco et al. 2008). The first insect population reported with resistance to a Vip toxin is a subpopulation of $H$. virescens collected from cotton fields in the USA in 2006 and selected with Vip3A in the laboratory (Pickett 2009; Gulzar et al. 2012).

Resistance management to insecticides is widely believed to depend in part on associated fitness costs; with the frequency of resistance alleles within a population declining in the absence of selection pressure (Tabashnik 1994), although some researchers consider that even strong fitness costs have only a minimal impact on the evolution of resistance (Roush 1998). Fitness costs can vary between different ecological and environmental conditions (Carrière and Tabashnik 2001; Bird and Akhrust 2007; Raymond et al. 2005; 2010; Gassmann et al. 2009).

Entomopathogenic nematodes (EPN) of the families Steinernematidae and Heterorhabditidae are used to control many insect pests (Ehlers 1996; Gouge et al. 1999; Liu and Yue 2000; Fitters et al. 2001; Susurluk et al. 2009; Rahoo et al. 2011; 2017;2018 a; b;2019 a; b; Javed et al. 2019 a; b). Infective nematode juveniles (IJ) may enter in the insect's haemocoel directly via thin parts of the cuticle, through the midgut epithelium via mouth or anus, or through the tracheae via spiracles (Koppenhöfer et al. 2000). Infective nematode juveniles release symbiotic bacteria into the insect haemocoel; the bacteria start to grow and release toxins that kill the host insect, usually within 24 to $48 \mathrm{~h}$ (Burnell and Stock 2000).

Entomopathogenic nematodes are being used as biological control agents against different insect pests. In laboratory experiment, Steinernema riobrave reduced survival of larvae, pupae and adults of red flour beetle, Tribolium castaneum (Ramos-Rodriguez et al. 2007). Larvae and adults of Indian meal moth, Plodia interpunctella (Hübner) (Lepidoptera: Pyralidae) were found to be susceptible to different heterorhabditid species in laboratory (Mbata and Shapiro-Ilan, 2005). Studies on the effects of entomopathogenic nematodes and baculoviruses on the fitness of Cry1Ac-selected P. gossypiella and $P$. xylostella have shown that both types of entomopathogens increase the fitness cost of resistance (Gassmann et al. 2006; 2009; Raymond et al. 2007; Hannon et al. 2010) and it has been suggested that the use of entomopathogens in Bt resistance management could increase the effectiveness of the use of refuges (Gassmann et al. 2008). In the present studies, fitness costs associated with the response to two entomopathogenic nematodes Steinernema carpocapsae and Heterorhabditis bacteriophora in Vip3A-Sel insects were investigated.

\section{MATERIALS AND METHODS}

\section{Insect culture}

Population of H. virescens used in the studies was collected from velvetleaf, Abutilon theophrasti, on Wildy Farms, Leachville, Mississippi County, Arkansas and designated as WF06. The WF06 population was divided into two subpopulations; one subpopulation (Vip-Sel) was selected with Vip3A toxin (Syngenta, Research Triangle, North Carolina, USA), the other subpopulation was left unselected (Vip-Unsel) (Pickett 2009; Gulzar et al. 2012). At the time of experiments the Vip-Sel resistance ratio was $>200$. 


\section{Nematodes}

Commercially-produced entomopathogenic nematodes, Steinernema carpocapsae (Weiser) (Nematoda: Rhaditida) and Heterorhabditis bacteriophora (Poinar) (Nematoda: Rhabditida) were obtained from Becker Underwood Ltd (Littlehampton, West Sussex, UK) and stored at $4^{\circ} \mathrm{C}$ prior to use. The nematodes were used within one week of storage.

\section{Nematode bioassays}

Mortality

Nematode bioassays were conducted on $2^{\text {nd }}, 3^{\text {rd }}, 4^{\text {th }}, 5^{\text {th }}$ and $6^{\text {th }}$ instar larvae of Vip3A-Sel and Unsel subpopulations of $H$. virescens. A preliminary experiment was conducted to check the effect of starvation on the insect larvae. The results indicated that there was no mortality for any instar of either subpopulation after 24 and $48 \mathrm{~h}$ periods of starvation. Subsequent bioassays were conducted in Petri dishes ( $5 \mathrm{~cm}$ dia.) containing a Whatman No. 1 filter paper ( $4.5 \mathrm{~cm} \mathrm{dia.)}$. Four hundred $\mu \mathrm{l}$ of water was applied to the filter paper to moisten it. A single insect larva was put in each Petri dish. Five nematode concentrations, i.e. $0,10,20,50,100$ and $150 \mathrm{IJ}$ in distilled water, were applied directly to the individual larvae by pipette. Insect mortality was noted after 24 and $48 \mathrm{~h}$. Surviving insect larvae were transferred to individual plastic cups (1 oz plastic cups, No. 9051, Bio-Serv, Frenchtown, NJ, USA) containing diet. Larvae that pupated were transferred to new containers and the emergence of adults was recorded. Twelve larvae per treatment were used in bioassays and the bioassay was replicated four times. Experiments were conducted at $25 \pm 5^{\circ} \mathrm{C}$ and $70 \% \pm 5 \% \mathrm{RH}$ under a 16-h-light/8-h-dark cycle.

\section{Nematode reproduction}

Reproduction of nematodes was determined in $2^{\text {nd }}, 3^{\text {rd }}, 4^{\text {th }}, 5^{\text {th }}$ and $6^{\text {th }}$ instar larvae of both subpopulations using the White Trap method (Kaya and Stock 1997). Five dead larvae per treatment from the above bioassay were placed in individual round plastic cups $(250 \mathrm{ml})$ and kept at $25^{\circ} \mathrm{C}$. After 2 weeks, the number of IJs that emerged from the insect cadavers in the water were counted under a stereomicroscope.

\section{Statistical analyses}

All data were analyzed using statistical program R version 2.9.0 (R Development Core Team 2009). Mortality data for both nematode species were corrected for control mortality using Abbott's correction (Abbott 1925) and subjected to analysis of covariance (ANCOVA). Nematode reproduction data for both nematode species were also analyzed by ANCOVA. Penetration data for both nematode species were log transformed and then analyzed by ANOVA.

\section{RESULTS}

\section{Effect of entomopathogenic nematodes on mortality of Vip3A-Sel and Unsel subpopulations of Heliothis virescens}

There was no survival in the Vip3A-Sel or Unsel subpopulations of $H$. virescens for $2^{\text {nd }}$, $3^{\text {rd }}$, and $4^{\text {th }}$ instar larvae after $48 \mathrm{~h}$ in any of the nematode treatments. The data were therefore excluded from the analysis. For $5^{\text {th }}$ instar larvae, mortality of the Unsel subpopulation after exposure to either nematode species for $48 \mathrm{~h}$ was significantly lower than the Vip3ASel subpopulation $(\mathrm{p}<0.05)$ (Fig. 1). The overall mortality of both subpopulations increased with increasing nematode 
concentration $(\mathrm{p}<0.001)$. The overall mortality caused by S. carpocapsae was significantly higher than that by $H$. bacteriophora in both Unsel and Vip3A-Sel subpopulations of H. virescens $(\mathrm{p}<0.001)$.

For $5^{\text {th }}$ instar larvae, mortality of the Unsel subpopulation after exposure to either nematode species at eclosion was significantly lower than the Vip3A-Sel subpopulation $(\mathrm{p}<0.05)$ as shown in Fig. 2.

Similarly, with the $6^{\text {th }}$ instar larvae of $H$. virescens, mortality in the Unsel subpopulation at $48 \mathrm{~h}$ and eclosion following exposure to either nematode species was significantly lower than in the Vip3A-sel subpopulation $(\mathrm{p}<0.05)$ and have been shown in Figs. 3 and 4. Mortality for both subpopulations and nematode species showed a general trend to increase with increasing nematode concentration $(\mathrm{p}<0.001)$.

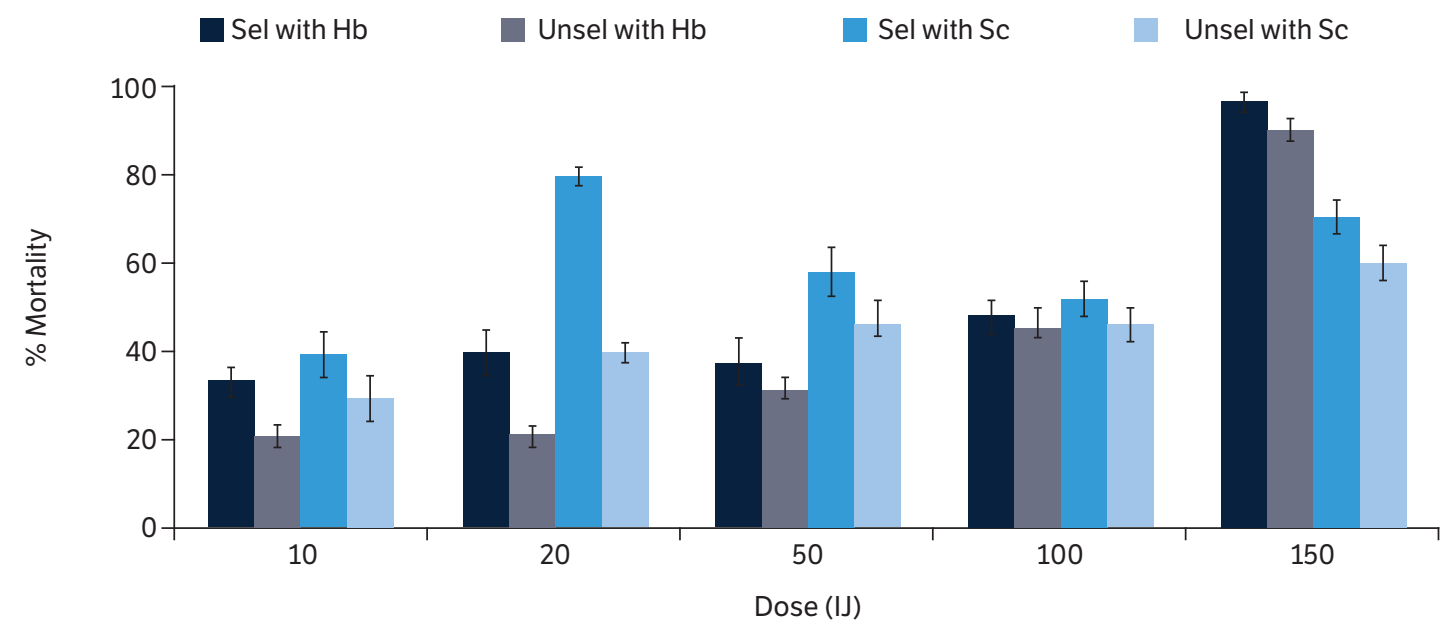

Figure 1. Mortality $(\% \pm S E)$ of $5^{\text {th }}$ instar larvae of Vip3A-Sel and Unsel subpopulations of Heliothis virescens at different concentrations of Steinernema carpocapsae and Heterorhabditis bacteriophora infective juveniles after $48 \mathrm{~h}$.

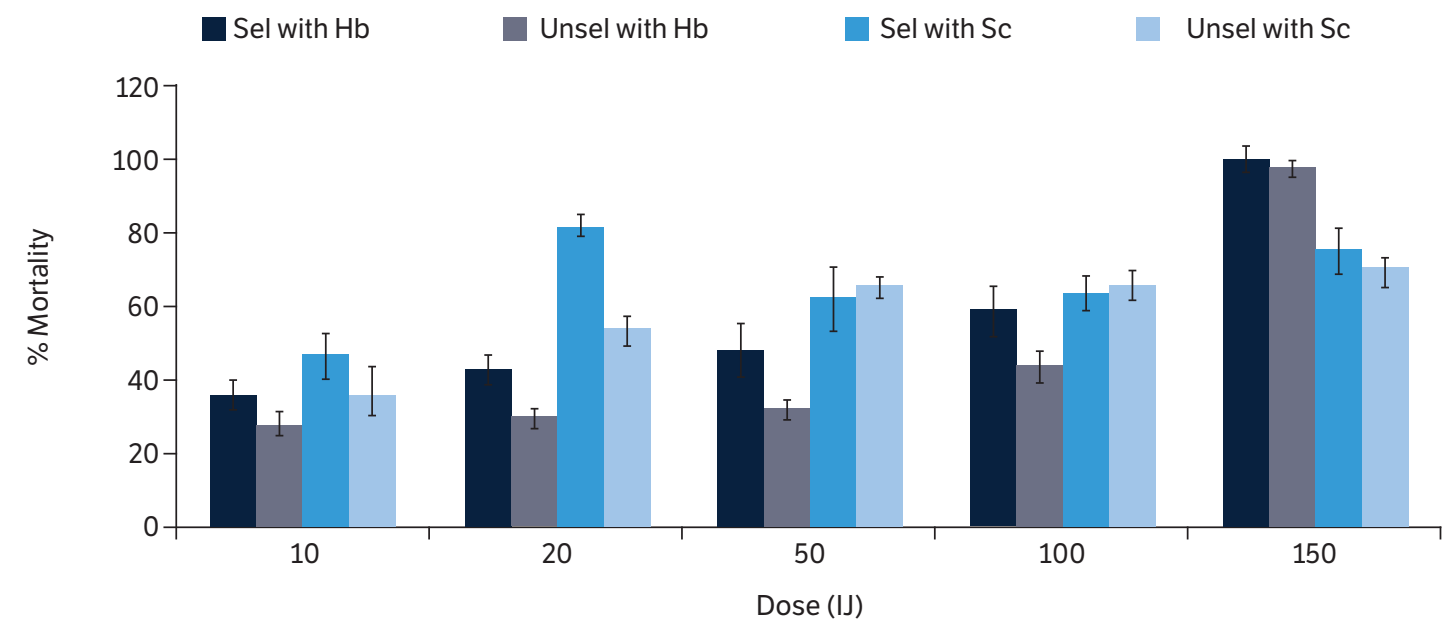

Figure 2. Mortality $(\% \pm \mathrm{SE})$ at eclosion following exposure of $5^{\text {th }}$ instar larvae of Vip3A-Sel and Unsel subpopulations of Helithis virescens to different concentrations of Steinernema carpocapsae and Heterorhabditis bacteriophora infective juveniles. 


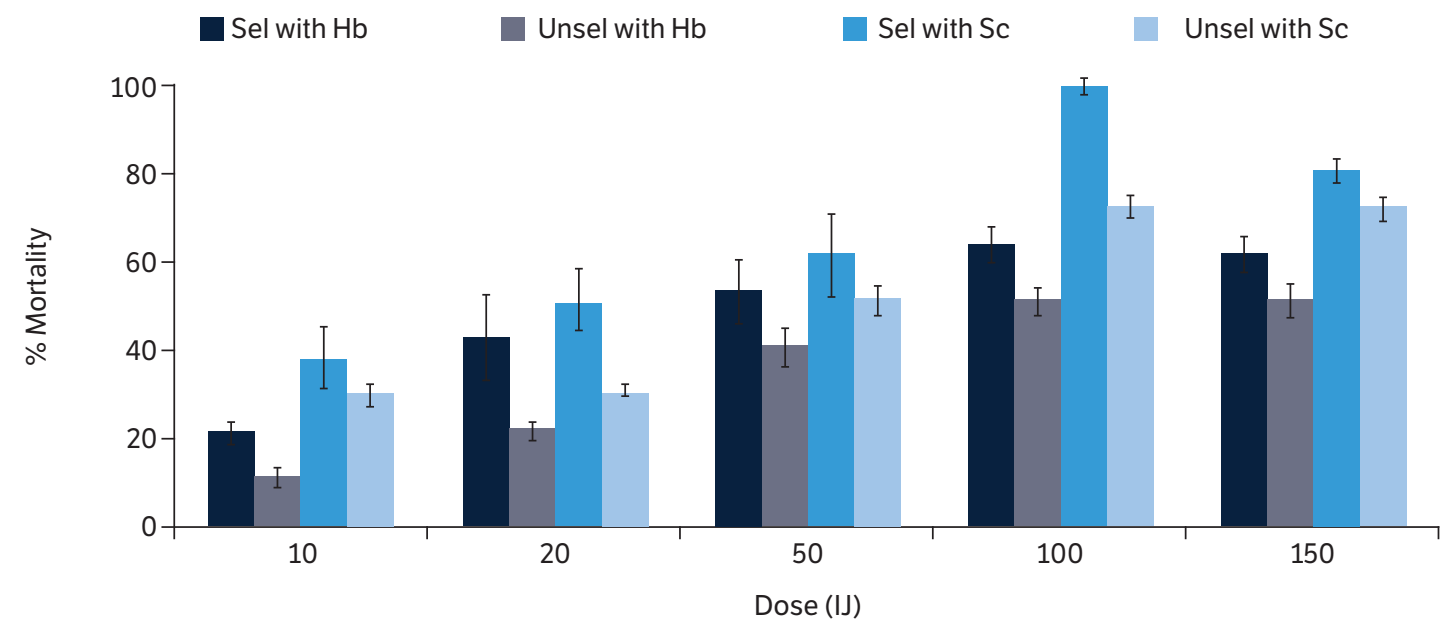

Figure 3. Mortality $(\%) \pm \mathrm{SE}$ at $48 \mathrm{~h}$ of $6^{\text {th }}$ instar larvae of Vip3A-sel and Unsel subpopulations of Heliothis virescens at different concentrations of Steinernema carpocapsae and Heterorhabditis bacteriophora infective juveniles.

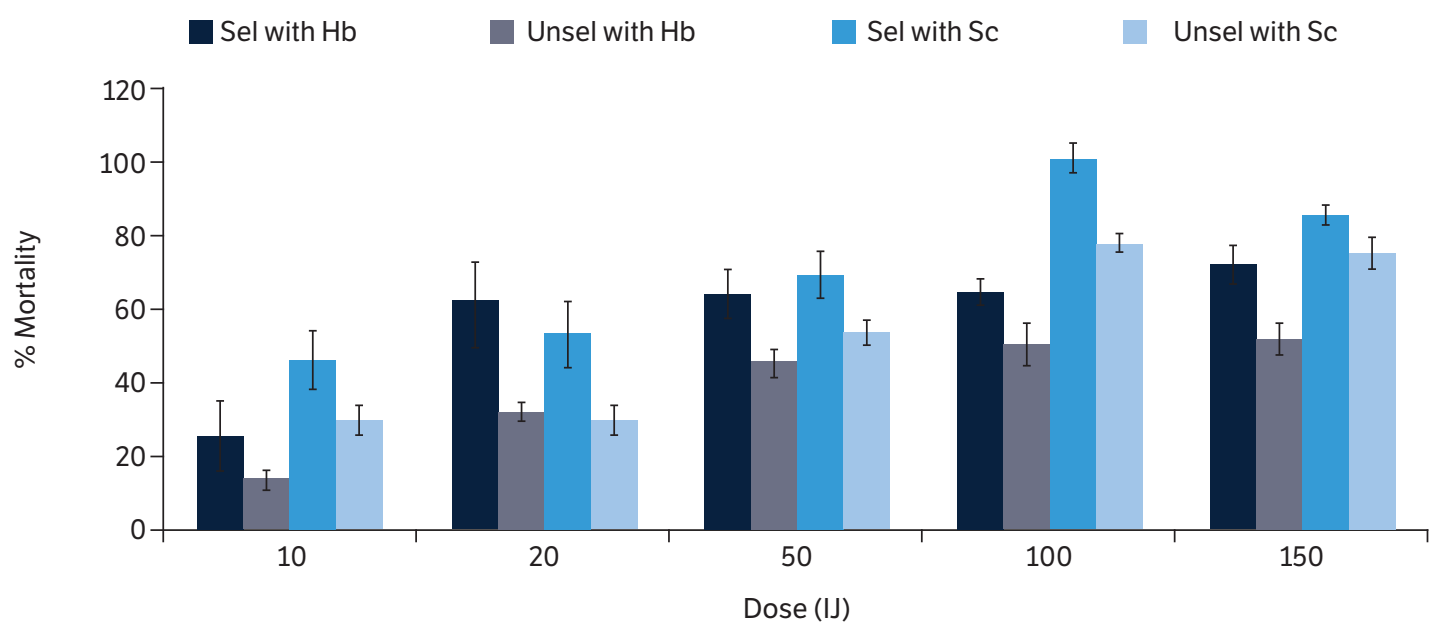

Figure 4. Mortality $(\%) \pm S E$ at eclosion of $6^{\text {th }}$ instar larvae of Vip3A-Sel and Unsel subpopulations of Heliothis virescens at different concentrations of Steinernema carpocapsae and Heterorhabditis bacteriophora infective juveniles.

\section{Nematode reproduction}

The overall reproduction of $S$. carpocapsae and H. bacteriophora was significantly greater in cadavers of the Unsel compared with the Vip3A-Sel subpopulation of $H$. virescens for all larval instars $(\mathrm{p}<0.001)$. The individual productions of IJs in each instar at different concentrations have been shown in Fig. 5 (a) to (e). There was a positive correlation between nematode reproduction and the larval instar infected with nematodes $(\mathrm{p}<0.001)$. 

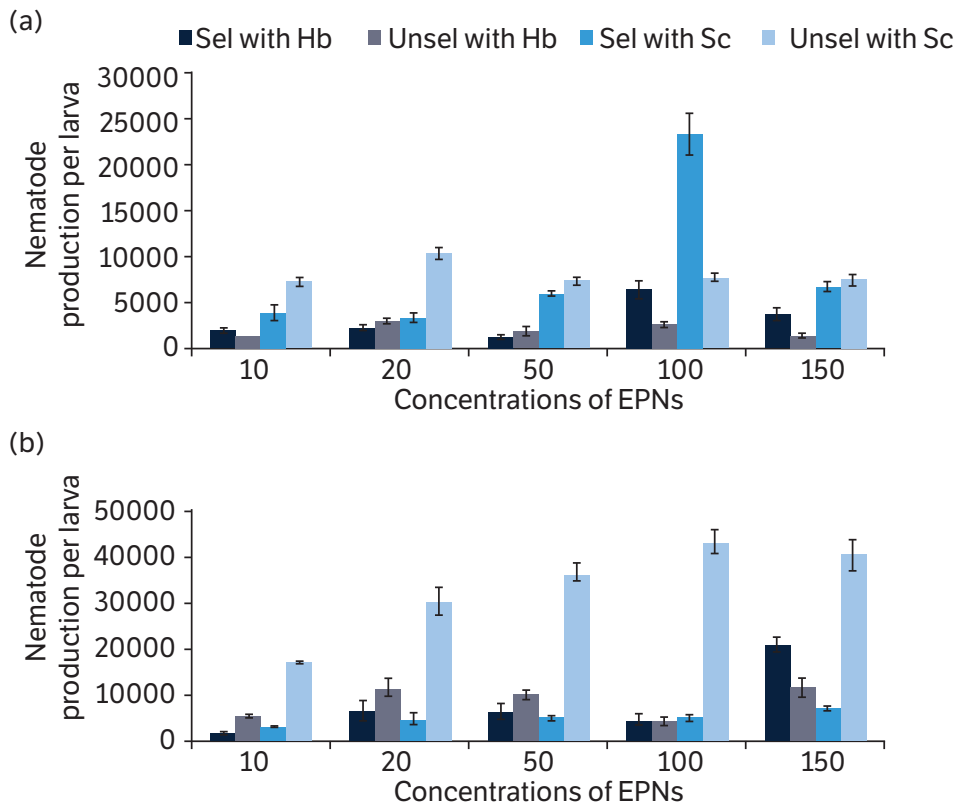

(c)

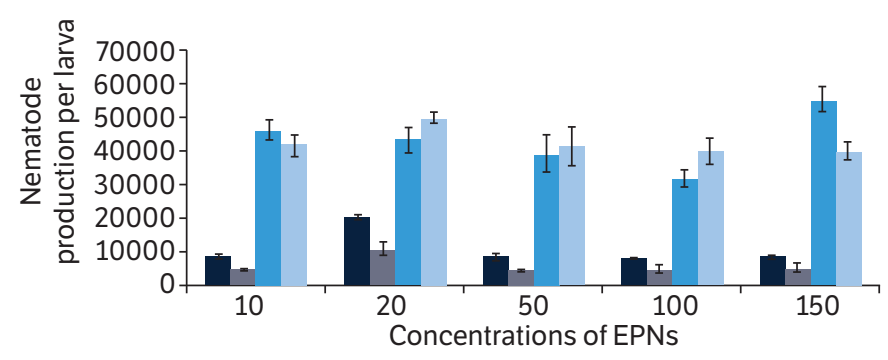

(d)
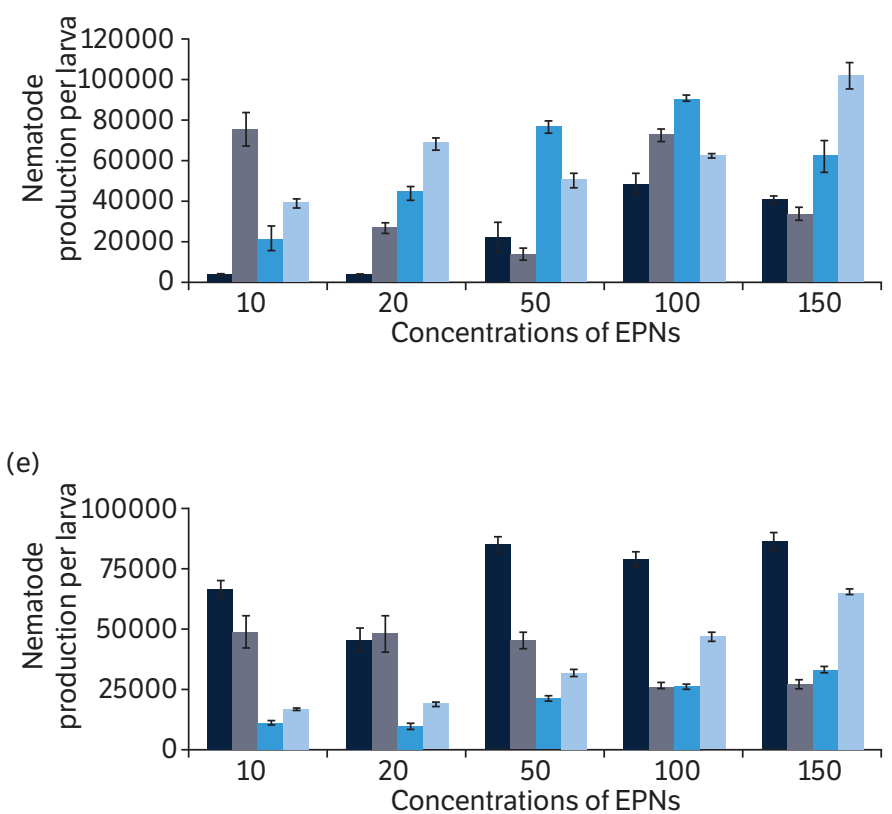

Figure 5. Reproduction \pm SE of Steinernema carpocapsae and Heterorhabditis bacteriophora in cadavers of $2^{\text {nd }}(a), 3^{\text {rd }}(b), 4^{\text {th }}(c), 5^{\text {th }}(d)$ and $6^{\text {th }}(e)$ instar larvae of Vip3A-Sel and Unsel subpopulations of Heliothis virescens at different nematode doses. 


\section{DISCUSSION}

The present study showed that $5^{\text {th }}$ and $6^{\text {th }}$ instar larvae of the Vip3A-Sel subpopulation of $H$. virescens were significantly more susceptible to both $S$. carpocapsae and H. bacteriophora compared with the Unsel subpopulation. These results, which suggest a fitness cost, are in accordance with previous studies, where $S$. carpocapsae marginally increased the fitness costs of Bt resistance in P. xylostella (Baur et al.1998) and S. riobrave and H. bacteriophora increased the fitness costs of Cryl1 Ac resistance in P. gossypiella (Gassmann et al. 2006; 2009). Raymond et al. (2007) have reported that baculoviruses (NPV) also increased the fitness costs of a Cryll Ac resistant population of $P$. xylostella. Lopez et al. (2010) also reported the similar findings that Nosema pyrausta delayed larval development of partially and fully Cryl1 Ab resistant Ostrinia nubilalis. Similarly, the nematode S. riobrave increased the fitness costs of resistance to Bt toxin Cry1 Ac in pink bollworm (Hannon et al. 2010).

The mechanisms by which the entomopathogenic nematodes cause greater mortality in Bt resistant insect populations remain unclear. The studies have shown that $\mathrm{CO}_{2}$ is involved in the long-distance attraction of plant parasitic and entomopathogenic nematodes (Klingler 1965; Lewis et al. 1993; Robinson 1995; Susurluk et al. 2009). One hypothesis is that the Bt toxin makes insects more debilitated and subsequently more susceptible to entomopathogens and these debilitated insects respire more and release more $\mathrm{CO}_{2}$; ultimately the selected population attract more EPNs. The other hypothesis is that $\mathrm{Bt}$ resistant insects show a reduced capacity to fend off pathogen infections compared with susceptible insects (Gassmann et al. 2006). For example, organophosphate resistant mosquitoes have been reported to have higher levels of Wolbachia infections than susceptible mosquitoes and to show a clear interaction between the presence of resistance alleles and Wolbachia load (Berticat et al. 2002).

Stress can reduce the general immunocompetence in insects against natural enemies. The major immune defense against endoparasitoids are encapsulation and melanization (Karimzadeh and Wright 2008). Insects may fend off infection from nematodes through encapsulation or melanization of nematode infective juveniles before they release bacteria (Li et al. 2007). Melanization occurs by the action of the prophenoloxidase pathway and difference in phenoloxidase activity could contribute to differences in susceptibility to pathogens between Bt resistant and susceptible insects (Gassmann et al. 2009). Bacillus thuringiensis resistance has been associated with higher phenoloxidase activity in Ephestia kuehniella and Helicoverpa armigera (Rahman et al. 2004; Ma et al. 2005), but it is not known whether these insects are susceptible to the entomopathogenic nematodes (Gassmann et al. 2009).

The present results indicate that $S$. carpocapsae imposed greater fitness costs compared with $H$. bacteriophora by causing greater mortality in the Vip3A resistant than in the susceptible population of $H$. virescens. This difference could be due to differences in the nematodes' behavior (Gaugler and Campbell 1993; Lewis et al. 1993; Boff et al. 2001; Susurluk et al. 2009) or to the different bacterial symbionts found in Steinernema (Xenorhabdus spp.) and Heterorhabitis (Photorhabdus spp.) species (Kaya and Gaugler 1993). Similarly, in the present study, penetration of IJs of both nematode species was greater in the Vip3A-Sel subpopulation than in the Unsel subpopulation of $H$. virescens. While the reason for this is unknown, it could be due to differences in insect behavior in the Petri bioassay. The greater number of IJ in Vip3A-Sel insects is the simplest explanation for the greater mortality in resistant insects rather than a reduced immune response. Further studies are required to determine whether Vip3A-resistant insects are more susceptible to entomopathogenic nematodes under conditions more relevant to the field.

\section{CONCLUSION}

The significant findings of the present study showed that Steinernema carpocapsae imposed greater fitness costs compared with Heterorhabditis bacteriophora by allowing greater penetration of infective juveniles and causing greater mortality in the Vip3A-Sel subpopulation than in the Unsel subpopulation of Heliothis virescens. It is therefore, concluded that entomopathogenic nematodes could increase the fitness costs and subsequently delay the resistance. 


\section{CONFLICT OF INTEREST}

The authors declare no conflict of interest.

\section{ACKNOWLEDGMENTS}

Asim Gulzar and Tariq Mukhtar were supported by the Higher Education Commission (Government of Pakistan). The authors are grateful to Dr. Andy Brown, Becker Underwood Ltd (Littlehampton, West Sussex, UK) for supply of entopathogenic nematodes. They are also grateful to Syngenta for supply of Vip3A and to Drs. Alan McCaffery, David O’Reilly and Ryan Kurtz (Syngenta) for their help and support. The work was conducted under Plant Health License No. PHL 189C/6086 (04/2009).

\section{AUTHOR'S CONTRIBUTION}

Conceptualization, Gulzar A. and Wright D. J.; Methodology, Gulzar A. and Mukhtar T.; Investigation, Gulzar A. and Mukhtar T; Writing - Original Draft, Gulzar A.; Writing - Review and Editing, Wright D. J. and Mukhtar T.; Funding Acquisition, Gulzar A.; Resources, Gulzar A. and Wright D. J.; Supervision, Wright D. J.

\section{REFERENCES}

Abbott, W. S. (1925). A method of computing the effectiveness of insecticides. Journal of Economical Entomology, 18, 265-267. https:// doi.org/10.1093/jee/18.2.265a

Baur, M. E., Kaya, H. K., Tabashnik, B. E. and Chilcutt, C. F. (1998). Suppression of diamondback moth (Lepidoptera: Plutellidae) with an entomopathogenic nematode (Rhabditida: Steinernematidae) and Bacillus thuringiensis Berliner. Journal of Economical Entomology, 91, 1089-1095. https://doi.org/10.1093/jee/91.5.1089

Berticat, C., Rousset, F., Raymond, M., Berthomieu, A. and Weill, M. (2002). High Wolbachia density in insecticide-resistant mosquitoes. Proceedings of the Royal Society B: Biological Sciences, 269, 1413-1416. https://doi.org/10.1098/rspb.2002.2022

Bird, L. J. and Akhurst, R. J. (2007). Effects of host plant species on fitness costs of Bt resistance in Helicoverpa armigera (Lepidoptera: Noctuidae). Biological Control, 40, 196-203. https://doi.org/10.1016/j.biocontrol.2006.11.004

Blanco, C. A., Terán-Vargas, A. P., Abel, C. A., Portilla, M., Rojas, M. G., Morales-Ramos, J. A. and Snodgrass, G. L. (2008). Plant host effect on the development of Heliothis virescens F. (Lepidoptera: Noctuidae). Environmental Entomology, 37, 1538-1547. https://doi. org/10.1603/0046-225X-37.6.1538

Boff, M. I. C., Wiegers, G. L., and Smits, P. H. (2001). Influence of insect larvae and plant roots on the host finding behaviour of Heterorhabditis megidis. Biocontrol Science and Technology, 11, 493-504. https://doi.org/10.1080/09583150120067526

Burnell, A. and Stock, S. P. (2000). Heterorhabditis, Steinernema and their bacterial symbionts-lethal pathogens of insects. Nematology, 2, 31-42. https://doi.org/10.1163/156854100508872

Carrière, Y. and Tabashnik, B. E. (2001). Reversing insect adaptation to transgenic insecticidal plants. Proceedings of the Royal Society B: Biological Sciences, 268, 1475-1480. https://doi.org/10.1098/rspb.2001.1689

Chakroun, M., Banyuls, N., Bel, Y., Escriche, B. and Ferré, J. (2016). Bacterial vegetative insecticidal proteins (Vip) from entomopathogenic bacteria. Microbiology and Molecular Biology Reviews, 80, 329-350. https://doi.org/10.1128/MMBR.00060-15 
Ehlers, R.-U. (1996). Current and future use of nematodes in biocontrol: practice and commercial aspects in regard to regulatory policies. Biocontrol Science and Technology, 6, 303-316. https://doi.org/10.1080/09583159631299

Estruch, J. J., Warren, G. W., Mullins, M. A., Nye, G. J., Craig, J. A. and Kozie, M. G. (1996). Vip3A, a novel Bacillus thuringiensis vegetative insecticidal protein with a wide spectrum of activities against lepidopteran insects. Proceedings of the National Academy of Sciences of the United States of America, 93, 5389-5394. https://doi.org/10.1073/pnas.93.11.5389

Ferré, J. and. Van Rie, J. (2002). Biochemistry and genetics of insect resistance to Bacillus thuringiensis. Annual Review of Entomology, 47, 501-533. https://doi.org/10.1146/annurev.ento.47.091201.145234

Fitt, G. P. (1989). The ecology of Heliothis species in relation to agroecosystems. Annual Review of Entomology, 34, 17-53. https://doi. org/10.1146/annurev.en.34.010189.000313

Fitters, P. F. L., Dunne, R. and Griffin, C. T. (2001). Improved control of Otiorhynchus sulcatus at $9{ }^{\circ} \mathrm{C}$ by cold-stored Heterorhabditis megidis UK211. Biocontrol Science and Technology, 11, 483-492. https://doi.org/10.1080/09583150120067517

Gassmann, A. J, Stock, S. P., Carrière, Y. and Tabashnik, B. E. (2006). Effect of entomopathogenic nematodes on the fitness cost of resistance to Bt toxin Cry1Ac in pink bollworm (Lepidoptera: Gelechiidae). Journal of Economic Entomology, 99, 920-926. https://doi. org/10.1093/jee/99.3.920

Gassmann, A. J., Stock, S. P., Sisterson, M. S., Carrière, Y. and Tabashnik, B. E. (2008). Synergism between entomopathogenic nematodes and Bacillus thuringiensis crops: integrating biological control and resistance management. Journal of Applied Ecology, 45, 957-966. https://doi.org/10.1111/j.1365-2664.2008.01457.x

Gassmann, A. J., Fabrick, J. A., Sisterson, M. S., Hannon, E. R., Stock, S. P., Carrière, Y. and Tabashnik, B. E. (2009). Effects of pink bollworm resistance to Bacillus thuringiensis on phenoloxidase activity and susceptibility to entomopathogenic nematodes. Journal of Economic Entomology, 102, 1224-1232. https://doi.org/10.1603/029.102.0348

Gatehouse, J. A. (2008). Biotechnological prospects for engineering insect-resistant plants. Plant Physiology, 146, 881-887. https://doi. org/10.1104/pp.107.111096

Gaugler, R. and Campbell, J. F. (1993). Nictation behaviour and its ecological implications in the host search strategies of entomopathogenic nematodes (Heterorhabditidae and Steinernematidae). Behaviour, 126, 155-169. https://doi.org/10.1163/156853993X00092

Gouge, D. H., Lee, L. L. and Henneberry, T. J. (1999). Parasitism of diapausing pink bollworm Pectinophora gossypiella (Lepidoptera: Gelechiidae) larvae by entomopathogenic nematodes (Nematoda: Steinernematidae, Heterorhabditidae). Crop Protection, $18,531-537$. https://doi.org/10.1016/S0261-2194(99)00057-5

Greenplate, J. T. (1999). Quantification of Bacillus thuringiensis insect control protein Cry1Ac over time in Bollgard cotton fruit and terminals. Journal of Economic Entomology, 92, 1377-1383. https://doi.org/10.1093/jee/92.6.1377

Gulzar, A., Pickett, B., Sayyed, A. H. and Wright, D. J. (2012). Effect of temperature on the fitness of a Vip3A resistant population of Heliothis virescens (Lepidoptera: Noctuidae). Journal of Economic Entomology, 105, 964-970. https://doi.org/10.1603/EC11110

Gulzar, A. and Wright, D. J. (2014). Fluctuating asymmetry, morphological changes and flight muscle ratio in a Vip3A resistant subpopulation of Heliothis virescens (WF06). International Journal of Agriculture and Biology, 16, 416-420.

Gulzar, A. and Wright, D. J. (2015). Sub-lethal effects of Vip3A toxin on survival, development and fecundity of Heliothis virescens and Plutella xylostella. Ecotoxicology, 24, 1815-1822. https://doi.org/10.1007/s10646-015-1517-6

Hannon, E. R., Sisterson, M. S., Stock, S. P., Carrière, Y., Tabashnik, B. E. and Gassmann, A. J. (2010). Effects of four nematode species on fitness costs of pink bollworm resistance to Bacillus thuringiensis toxin Cry1Ac. Journal ofEconomic Entomology,103,1821-1831. https://doi.org/10.1603/EC10087 
Hernández-Martínez, P., Hernández-Rodríguez, C. S., Van Rie, J., Escriche, B. and Ferré, J. (2013). Insecticidal activity of Vip3Aa, Vip3Ad, Vip3Ae, and Vip3Af from Bacillus thuringiensis against lepidopteran corn pests. Journal of Invertebrate Pathology, 113, 78-81. https:// doi.org/10.1016/j.jip.2013.02.001

Jackson, R. E., Marcus, M. A., Gould, F., Bradley Junior, J. R. and Van Duyan, J. W. (2007). Cross resistance responses of Cry1Ac-selected Heliothis virescens (Lepidoptera: Noctuidae) to the Bacillus thuringiensis protein Vip3A. Journal of Economic Entomology, 100, $180-186$. https://doi.org/10.1093/jee/100.1.180

Janmaat, A. F. and Myers, J. H. (2005). The cost of resistance to Bacillus thuringiensis varies with the host plant of Trichoplusia ni. Proceedings of the Royal Society B: Biological Sciences, 272, 1031-1038. https://doi.org/10.1098/rspb.2004.3040

Javed, K., Javed, H., Mukhtar, T. and Qiu, D. (2019 a). Efficacy of Beauveria bassiana and Verticillium lecanii for the management of whitefly and aphid. Pakistan Journal of Agricultural Sciences, 56, 669-674.

Javed, K., Javed, H., Mukhtar, T. and Qiu, D. (2019 b). Pathogenicity of some entomopathogenic fungal strains to green peach aphid, Myzus persicae Sulzer (Homoptera: Aphididae). Egyptian Journal of Biological Pest Control, 29, 92, https://doi.org/10.1186/s41938-019-0183-z

Karimzadeh, J. and Wright, D. J. (2008). Bottom-up cascading effects in a tritrophic system: interactions between plant quality and hostparasitoid immune responses. Ecological Entomology, 33, 45-52.

Kaya, H. K. and Gaugler, R. (1993). Entomopathogenic nematodes. Annual Review of Entomology, 38, 181-206. https://doi.org/10.1146/ annurev.en.38.010193.001145

Kaya, H. K. and Stock, S. P. (1997). Techniques in insect Nematology. In Manual of techniques in insect pathology: Biological Techniques Series (pp. 281-324). San Diego: Academic Press. https://doi.org/10.1016/B978-012432555-5/50016-6

King, A. B. S. (1994). Heliothis helicoverpa (Lepidoptera: Noctuidae). In G. A. Matthews and J. P. Tunstall (Eds.). Insect Pests of Cotton (pp. 39-106). Wallingford: CAB International.

Klingler, J. (1965). On the orientation of plant nematodes and of some other soil animals. Nematologica, 11, 4-18. https://doi. org/10.1163/187529265X00438

Koppenhöfer, A. M., Grewal, P. S. and Kaya, H. K. (2000). Synergism of imidacloprid and entomopathogenic nematodes against white grubs: the mechanism. Entomologia Experimentalis et Applicata, 94, 283-293. https://doi.org/10.1046/j.1570-7458.2000.00630.x

Lee, M. K., Walters, F. S., Hart, H., Palekar, N. and Chen, J.-S. (2003). Mode of action of the Bacillus thuringiensis vegetative insecticidal protein Vip3A differs from that of Cry1Ab $\delta$-endotoxin. Applied and Environmental Microbiology, 69, 4648-4657. https://doi.org/10.1128/ AEM.69.8.4648-4657.2003

Lewis, E. E, Gaugler, R. and Harrison, R. (1993). Response of cruiser and ambusher entomopathogenic nematodes (Steinernematidae) to host volatile cues. Canadian Journal of Zoology, 71, 765-769. https://doi.org/10.1139/z93-101

Li, X.-Y., Cowles, R. S., Cowles, E. A., Gaugler, R. and Cox-Foster, D. L. (2007). Relationship between the successful infection by entomopathogenic nematodes and the host immune response. International Journal of Parasitology, 37, 365-374. htps://doi.org/10.1016/j.ijpara.2006.08.009

Liu, N. and Yue, X. (2000). Insecticide resistance and cross-resistance in the house fly (Diptera: Muscidae). Journal of Economic Entomology, 93, 1269-1275. htps://doi.org/10.1603/0022-0493-93.4.1269

Llewellyn, D. J., Mares, C. L. and Fitt, G. P. (2007). Field performance and seasonal changes in the efficacy against Helicoverpa armigera (Hübner) of transgenic cotton expressing the insecticidal protein Vip3A. Agriculture and Forest Entomology, 9, 93-101. htps://doi. org/10.1111/j.1461-9563.2007.00332.x

Lopez, M. D., Sumerford, D. V. and Lewis, L. C. (2010). Effects of infection with Nosema pyrausta on survival and development of offspring of laboratory selected Bt-resistant and Bt-susceptible European corn borers. Journal of Invertebrate Pathology, 105, 248-253. htps:// doi.org/10.1016/j.jip.2010.07.004 
Ma, G., Roberts, H., Sarjan, M., Featherstone, N., Lahnstein, J., Akhurst. R. and Schmidt, O. (2005). Is the mature endotoxin Cry1Ac from Bacillus thuringiensis inactivated by a coagulation reaction in the gut lumen of resistant Helicoverpa armigera larvae? Insect Biochemistry and Molecular Biology, 35, 729-739. htps://doi.org/10.1016/j.ibmb.2005.02.011

Mbata, G. N. and Shapiro-Ilan, D.I. (2005). Laboratory evaluation of virulence of heterorhabditid nematodes to Plodia interpunctella Hübner (Lepidoptera: Pyralidae). Environmental Entomology, 34, 676-682. htps://doi.org/10.1603/0046-225X-34.3.676

McCaffery, A. R. (1998). Resistance to insecticides in Heliothine (Lepidoptera): a global view. Philosophical Transactions of the Royal Society B: Biological Sciences, 353, 1735-1750. htps://doi.org/10.1098/rstb.1998.0326

Neunzig, H. (1969). The biology of the tobacco budworm and the corn earworm in North Carolina: with particular reference to tobacco as a host. North Carolina: North Carolina Agricultural Experiment Station.

Pickett, B. (2009). Studies on resistance to vegetative (Vip3A) and crystal (Cry1A) insecticide toxins of Bacillus thuringiensis in Heliothis virescens (Fabricius). (Thesis in Philosophy). Imperial College London, London.

R Development Core Team (2009) R: A language and environment for statistical computing. Vienna: R Foundation for Statistical computing. Available at: http://www.R-project .org

Rahman, M. M., Roberts, H. L. S., Sarjan, M., Asghari, S. and Schmidt, O. (2004). Induction and transmission of Bacillus thuringiensis tolerance in the flour moth Ephestia kuehniella. Proceedings of the National Academy of Sciences of the United States of America, 101, 2696-2699. htps://doi.org/10.1073/pnas.0306669101

Rahoo, A. M., Mukhtar, T., Gowen, S. R. and Pembroke, B. (2011). Virulence of entomopathogenic bacteria Xenorhabdus bovienii and Photorhabdus luminescens against Galleria mellonella larvae. Pakistan Journal of Zoology, 43, 543-548.

Rahoo, A. M., Mukhtar, T., Gowen, S. R., Rahoo, R. K. and Abro, S. I. (2017). Reproductive potential and host searching ability of entomopathogenic nematode, Steinernema feltiae. Pakistan Journal of Zoology, 49, 229-234. https://doi.org/10.17582/journal.pjz/2017.49.1.229.234

Rahoo, A. M., Mukhtar, T., Abro, S. I., Bughio, B. A. and Rahoo, R. K. (2018 a). Comparing the productivity of five entomopathogenic nematodes in Galleria mellonella. Pakistan Journal of Zoology, 50, 679-684. https://doi.org/10.17582/journal.pjz/2018.50.2.679.684

Rahoo, A. M., Mukhtar, T., Jakhar, A. M. and Rahoo, R. K. (2018 b). Inoculum doses and exposure periods affect recovery of Steinernema feltiae and Heterorhabditis bacteriophora from Tenebrio molitor. Pakistan Journal of Zoology, 50, 983-987. https://doi.org/10.17582/journal.pjz/2018.50.3.983.987

Rahoo, A. M., Mukhtar, T., Bhugio, B. A. and Rahoo, R. K. (2019 a). Comparison of infectivity and productivity of Steinernema feltiae and Heterorhabditis bacteriophora in Galleria mellonella and Tenebrio molitor. Pakistan Journal of Zoology, 51,717-724. htps://doi.org/10.17582/ journal.pjz/2019.51.2.717.724

Rahoo, A. M., Mukhtar, T., Bughio, B. A. and Rahoo, R. K. (2019 b). Relationship between the size of Galleria mellonella larvae and the production of Steinernema feltiae and Heterorhabditis bacteriophora. Pakistan Journal of Zoology, 51, 79-84.

Ramos-Rodríguez, O., Campbell, J.F. and Ramaswamy, S.B. (2007). Efficacy of the entomopathogenic nematode Steinernema riobrave against the stored-product insect pests Tribolium Castaneum and Plodia Interpunctella. Biological Control, 40, 15-21. https://doi. org/10.1016/j.biocontrol.2006.09.007

Raymond, B., Hartley, S. E., Cory, J. S. and Hails, R. S. (2005). The role of food plant and pathogen-induced behaviour in the persistence of a nucleopolyhedrovirus. Journal of Invertebrate Pathology, 88, 49-57. https://doi.org/10.1016/j.jip.2004.09.005

Raymond, B., Sayyed, A. H., Hails, R. S. and Wright, D. J. (2007). Exploiting pathogens and their impact on fitness costs to manage the evolution of resistance to Bacillus thuringiensis. Journal of Applied Ecology, 44, 768-780. htps://doi.org/10.1111/j.1365-2664.2007.01285.x

Raymond, B., Wyres, K. L., Sheppard, S. K., Ellis, R. J. and Bonsal, M. B. (2010). Environmental factors determining the epidemiology and population genetic structure of the Bacillus cereus group in the field. Plos Pathogens, 6, 1-13. https://doi.org/10.1371/journal.ppat.1000905 
Robinson, A. F. (1995). Optimal release rates for attracting Meloidogyne incognita, Rotylenchus reniformis and other nematodes to carbon dioxide in sand. Journal of Nematology, 27, 42-50.

Roush, R. T. (1998). Two-toxin strategies for management of insecticidal transgenic crops: can pyramiding succeed where pesticide mixtures have not? Philosophical Transactions of Royal Society B: Biological Sciences, 353, 1777-1786. htps://doi.org/10.1098/rstb.1998.0330

Selvapandiyan, A., Arora, N., Rajgopal, R., Jalali, S. K., Venkatesan, T., Singh, S. P. and Bhatnagar, R. K. (2001). Toxicity analysis of N- and C-terminus-deleted vegetative insecticidal protein from Bacillus thuringiensis. Applied and Environmental Entomology, 67, 5855-5858. htps://doi.org/10.1128/AEM.67.12.5855-5858.2001

Sudbrink Junior, D. L. and Grant, J. F. (1995). Wild host plants of Helicoverpa zea and Heliothis virescens (Lepidoptera: Noctuidae) in Eastern Tennessee. Environmental Entomology, 24, 1080-1085. htps://doi.org/10.1093/ee/24.5.1080

Susurluk, I. A., Kumral, N. A., Peters, A., Bilgili, U. and Açıkgöz, E. (2009). Pathogenicity, reproduction and foraging behaviours of some entomopathogenic nematodes on a new turf pest, Dorcadion pseudopreissi (Coleoptera: Cerambycidae). Biocontrol Science and Technology, 19, 585-594. htps://doi.org/10.1080/09583150902957348

Tabashnik, B. E. (1994). Evolution of resistance to Bacillus thuringiensis. Annual Review of Entomology, 39, 47-79. https://doi.org/10.1146/ annurev.en.39.010194.000403

Terán-Vargas, A. P., Rodríguez, J. C., Blanco, C. A., Martínez-Carrillo, J. L., Cibrián-Tovar, J., Sánchez-Arroy, H., Rodríguez-Del-Bosque, L. A. and Stanley, D. (2005). Bollgard cotton and resistance of tobacco budworm (Lepidoptera: Noctuidae) to conventional insecticides in southern Tamaulipas, Mexico. Journal of Economic Entomology, 98, 2203-2209.

Warren, G. W. (1997). Vegetative insecticidal protein: novel proteins for control of corn pests. In N. Carozzi and M. Koziel (Eds.). Advances in insect control: The role of transgenic plants (p. 109-121). London: Taylor and Francis Ltd. 